Mediaciones Sociales

ISSN-e: 1989-0494

\title{
A patologização da gravidez e o aborto na mediatização da epidemia de Zika ${ }^{1}$ \\ Juliana Alcantara ${ }^{2}$
}

Resumo. A problematização da microcefalia nos bebés das grávidas infetadas pelo vírus da Zika insuflou a discussão sobre a legalização do aborto no ano de 2016 no Brasil. Esta investigação tem como abordagem a perspetiva feminista e analisa artigos das edições online da Folha de S.Paulo e de $O$ Globo no respetivo ano a partir da Análise Crítica do Discurso. O objetivo é perceber quais padrões discursivos foram dinamizados na cobertura jornalística. Os resultados mostram que a cobertura noticiosa privilegiou os âmbitos médico, jurídico, político e religioso, e reservou a relação Zika-microcefalia às mulheres jovens e periféricas.

Palavras-chave: epidemia; saúde pública; Zika; aborto; jornalismo.

\section{[en] The pathologization of pregnancy and abortion in the mediatization of the Zika epidemic}

\begin{abstract}
The problematization of microcephaly in the babies of pregnant women infected with the Zika virus sparked the debate on the legalization of abortion in 2016 in Brazil. This investigation takes as its approach the feminist perspective and analyses articles from the online editions of Folha de S.Paulo and $O$ Globo in the respective year, based on the Critical Discourse Analysis. The aim is to understand which discursive patterns were dynamized in journalistic coverage. The results show that the news coverage bolsters the medical, legal, political, and religious spheres, and reserved the Zika-microcephaly relationship for young and peripheral women. Keywords: epidemic; public health; Zika; abortion; journalism.
\end{abstract}

Sumario: 1. Introdução. 2. Escopo teórico. 2.1. Mediatização da doença e da saúde. 2.2. Discurso e poder. 3. Abordagem metodológica. 4. Apresentação e discussão de resultados. 4.1. Âmbito médico. 4.2. Âmbito jurídico. 4.3. Âmbito político. 4.4. Âmbito religioso.

5. Conclusão. 6. Referências bibliográficas.

Cómo citar: Alcantara, J. A patologização da gravidez e o aborto na mediatização da epidemia de Zika. en Mediaciones Sociales (2021), 1-11.

\section{Nota biográfica}

Juliana Alcantara, Universidade de Coimbra (Portugal): Doutoranda em Ciências da Comunicação e mestre em Jornalismo e Comunicação pela Faculdade de Letras da Universidade de Coimbra (FLUC). Pósgraduada em Comunicação Empresarial e em Docência do Ensino Superior. Bacharel em Comunicação Social com habilitação em Jornalismo. Possui mais de dez anos de experiência profissional como assessora de comunicação e jornalista. Os interesses de pesquisa incidem nos tópicos: jornalismo, comunicação e saúde, género e literacia mediática.

\section{Introdução}

Epidemia, risco, ameaça, crise, morte, contaminação, todas são palavras que constantemente retornam ao nosso vocabulário quando algum mal patológico envolve e interfere no quotidiano. Embora remetamos esses termos ao significado de doença, seu antónimo não é saúde. Como define a Organização Mundial da Saúde, o conceito de ser saudável abrange "um estado de completo bem-estar físico, mental e social e não

Uma versão parcial e resumida desta investigação foi apresentada durante o Congresso de Género e Comunicação GenderCom 2021.

Juliana Alcantara, Universidade de Coimbra (Portugal) 
apenas a ausência de doença ou enfermidade" ${ }^{3}$. Biologicamente, homens e mulheres respondem de maneiras diferentes às condições de doença e de saúde. Socialmente, as diferenças podem agravar, amenizar, suspender ou tardar certas disposições genéticas (Regitz-Zagrosek \& Seeland, 2013; Hamberg, 2008). Não é raro vermos determinados riscos potencializados para o corpo feminino, como por exemplo o cancro de mama, ainda que homens também o possam desenvolver. O mesmo caso se aplica para o enfarte e as questões de coração, tão comummente designados aos homens pelos media. $\mathrm{O}$ facto é que, apesar dos dois sexos carregarem particularidades, é o corpo da mulher que é frequentemente posto no centro das discussões de saúde num movimento que vai além do corpo per se, avança para os costumes, para as atitudes com a sociedade e para com os grupos aos quais faz parte, para os comportamentos consigo própria e para modos de pensar que as libertam por um lado e as aprisionam por outro.

A epidemia do vírus Zika fez com que duas palavras entrassem, em 2016, no repertório mediático: microcefalia e aborto. $\mathrm{O}$ surto fez reacender a discussão do direito a interrupção da gravidez, uma temática por vezes restrita ao corpo da parturiente, que exclui a decisão da mulher e a outra parte envolvida, o pai, e que abrange instituições sociais. No Brasil, segundo o Código Penal (1940), o aborto é permitido somente nos casos de estupro, risco de vida da gestante e, a partir de 2012, em casos de anencefalia. De acordo com a Pesquisa Nacional de Aborto 2016 (Diniz, Medeiros \& Madeiro, 2017), o aborto é uma prática regular e que persiste entre as mulheres independentemente da sua classe social, etnia, nível educacional e religião, embora haja maior frequência entre aquelas que possuem menor escolaridade, e são pretas, pardas e indígenas que vivem nas regiões Norte, Nordeste e Centro-Oeste. Segundo o relatório, em 2016, uma em cada cinco mulheres, aos 40 anos, já realizou pelo menos uma vez o aborto.

Até fevereiro de 2016, ano em que o Rio de Janeiro foi a cidade sede das Olimpíadas, e ano também marcado pelo impeachment da presidente Dilma Rousseff, mais de vinte países relataram a transmissão local do vírus Zika. Com o surto de milhares de casos, a OMS chegou a declarar Emergência de Saúde Pública de Interesse Internacional após a confirmação de que os quadros de bebés com microcefalia e outros distúrbios neurológicos que afetavam o desenvolvimento dos fetos estavam diretamente ligados às grávidas infetadas (Rubin et al., 2016; Castilhos, 2018). Todavia, em maio de 2019, o Supremo Tribunal Federal retirou da agenda o julgamento que descriminalizaria o aborto em casos de gravidez em mulheres infetadas com o vírus.

No presente estudo averiguaremos, sob a perspetiva feminista, como os discursos médicos e políticos foram articulados nos media brasileiros e como o corpo da mulher foi construído a partir da prática discursiva jornalística durante a epidemia de Zika. Embora outras práticas discursivas estejam presentes e entrelaçadas, como a legislatura no caso de descriminalização do aborto para mulheres grávidas infetadas pelo vírus Zika, o que importa perceber é como as notícias apresentaram e relacionaram os assuntos Zika e aborto e como dois jornais brasileiros de reconhecida audiência, em suas versões online, Folha de S.Paulo e O Globo enquadraram os tópicos em concomitância.

O artigo começa por tratar das relações dos media com a saúde e a doença e, de seguida, apresenta estudos sobre a mediatização noticiosa da Zika. Ainda na parte introdutória, os conceitos de discurso e o poder como abrangidos por Michel Foucault são discutidos. Investigaremos como o poder é exercido na esfera linguística, tendo em conta as peças jornalísticas que relacionam a doença com o aborto. Para orientar a investigação, foi elegida a análise no discurso com inspiração foucauldiana porque consideramos que o "conhecimento produzido pelas disciplinas linguísticas sobre a língua e os falantes acaba regulamentando o comportamento dos indivíduos e da população em geral”4 (Martín Rojo, 2015, p. 15).

\section{Escopo teórico}

\subsection{Mediatização da doença e da saúde}

A saúde não é simplesmente um assunto de âmbitos biológico e psicológico, é também intrinsecamente de caráter social (Chamberlain, Stephens \& Lyons, 1997). Só é possível entender as mudanças dos corpos quando a análise permite considerar as estruturas cultural e social em que os indivíduos estão inseridos (Lyons, 2000, p. 354). Portanto, as representações da saúde são implicações de amplo e contínuo alcance e que englobam experiências individuais e em grupo.

Quando falamos dos media, o seu potencial de influência na perceção do risco é fator indissociável dos comportamentos adquiridos (Jerit, et al., 2018; Frewer, 2001; Sell et al., 2018). O impacto na saúde pode estar vinculado a um contexto de crise ou a um perigo crônico, que pode representar constantemente uma ameaça (Frewer, 2001), mas é sobretudo nas atitudes, nas crenças e nas subjetividades que os media atuam. As campanhas de promoção da saúde pública que disseminam em massa mensagens "saudáveis" são exemplos disso (Lupton, 1992). Deborah Lupton (1992) investigou dois artigos sobre o caso de uma criança que faleceu

Disponível em: https://www.who.int/governance/eb/who_constitution_sp.pdf?ua=1

Tradução própria. 
em decorrência da Sida e recebeu ampla cobertura da imprensa australiana em 1990. As particularidades discursivas expõem uma linguagem emotiva ao relatar a luta contra a doença e a morte da menina. $\mathrm{O}$ estudo da autora expõe um enfoque sobre a gravidade do vírus HIV/Sida e uma ausência de simpatia por outras pessoas seropositivas. Para a autora, uma análise de conteúdo quantitativa esconderia nos números "o que foi dito", sem a possibilidade de correlacionar texto e contexto, o que ocultaria a análise das estruturas de poder e ideologias dominantes, que são refletidas e perpetuadas pela linguagem (Lupton, 1990).

As investigações existentes sobre o assunto Zika focam especialmente no período do agravamento da epidemia no Brasil e a realização dos Jogos Olímpicos no Rio de Janeiro. Os resultados de Aguiar e Araújo (2016) revelam grande agendamento sobre o tema nas capas de jornais. Os veículos de maior audiência iniciaram ao mesmo tempo as publicações, em novembro de 2015, mês do anúncio da situação de Emergência em Saúde Pública, e as palavras "medo" e "risco" foram utilizadas com frequência.

A diferença de abordagem ao assunto entre os jornais do Sul e do Nordeste do Brasil mostrou a associação da doença às/aos nordestinas/os, acirrando as diferenciações sociais entre as regiões do país (Danfá \& Moraes, 2017). O contexto do surgimento da epidemia e a "construção da atmosfera do risco" foram evidenciados e posicionamentos político-ideológicos emergiram. As Olimpíadas receberam mais atenção e também foram relacionadas às preocupações em relação à saúde dos atletas e participantes dos comitês olímpicos (Maia \& Yagui, 2017; Martins, 2016).

No período pré-olímpico, enfoques dramáticos foram privilegiados na programação televisiva de fim de semana, enquanto que registos mais objetivos dominaram o horário nobre do jornalismo. Em contrapartida, em nenhum dos casos houve problematização da relação entre a doença Zika, e o risco iminente dos bebés das gestantes portadoras do vírus Zika desenvolverem deficiências relacionadas à microcefalia trouxe à tona as argumentações sobre o direito ao aborto (Cardoso, Câmara \& Fiorito, 2017). Tal problemática pautou a pesquisa de Porto e Moura (2017, p. 177), que apontaram razões ideológicas a partir de "discursos religiosos, morais, científicos e políticos". As autoras pontuaram o descaso das autoridades não só com a saúde per se, mas inclusive com a falta de infraestrutura e de saneamento. Além disso, as cidadãs e os cidadãos foram responsabilizadas/os, o pânico foi generalizado com a iminente expansão do vírus, e as mulheres foram tidas como as únicas responsáveis pela contraceção e um eventual impedimento da gravidez.

A maneira com que as mulheres foram representadas nos media também foi levada em conta nas investigações brasileiras e internacionais. No caso brasileiro, as vozes das mulheres afetadas pelo vírus foram silenciadas e as fontes especializadas, médicas e jurídicas, foram privilegiadas. Quando o aborto entrou em questão, as fontes que eram favoráveis denunciaram especialmente as injustiças sociais e as fontes contrárias reagiram com o discurso em defesa da vida (Castilhos \& Almeida, 2020). A forma como o discurso noticioso foi construído mostrou uma projeção de grupos específicos como responsáveis pela disseminação da doença, ao explorar a interseccionalidade de género, raça, etnia, classe social e nacionalidade (Fabrício, 2019). No contexto norteamericano, as mulheres foram representadas como sendo as fontes da doença, independentemente do homem ou de outros vetores de transmissão. As estadunidenses foram consideradas as mais privilegiadas, em termos de decisão e controlo sobre seus próprios corpos, do que as mulheres da América do Sul. Os discursos da ciência e da religião representaram outras culturas como mais opressivas e perigosas para as mulheres.

A crise epidémica surtiu efeito na opinião pública nas eleições de 2016, que alçaram Donald Trump a presidente dos Estados Unidos. Investigações indicaram que a maneira com que o assunto Zika foi abordado influenciou no voto e nas atitudes da população sobre o aborto tardio (Jerit et al., 2018). Os media direcionaram o discurso sobretudo para as mulheres grávidas e a transmissão sexual do vírus. A discussão sobre gestação foi tão intensa que pouca atenção foi dada à transmissão da doença pelo mosquito Aedes Aegypti (Sell et al., 2018).

\subsection{Discurso e poder}

O poder para Foucault é algo que permeia toda a sociedade e é exercido através de práticas, não existindo, portanto, o poder per se. Ou seja, para o poder existir e se manter é necessário um conjunto de ações que atuem no corpo social. Porém, isto não é o mesmo que dizer que não haja instituições de poder, pelo contrário, as instituições atuam através de regimes de poder e utilizam práticas para manter o controlo. Foucault apontou as práticas punitivas e disciplinares nas prisões, nas escolas, nas famílias e no exército, as confissões católicas para o que diz respeito à sexualidade, e as práticas discursivas para a medicina e a loucura. O que Foucault fez não foi estudar o poder, mas sim desconstruir os sistemas historicizados tendo como objeto de estudo o sujeito. O objetivo é entender o sujeito e como ele é constituído. Portanto, o que interessava para Foucault era investigar como e porque algumas formas de pensar foram consideradas verdade enquanto outras foram descartadas e quais foram os efeitos para o indivíduo 5 .

\footnotetext{
Nas palavras de Foucault: "para que a análise tenha um alcance político, é preciso que incida não sobre a génese das verdades ou a memória dos erros. Saber quando tal ciência começou a dizer a verdade, que importa? Recordar todos os erros que os médicos disseram sobre o sexo ou sobre a loucura, de nada nos serve... Penso que aquilo que tem importância política actual é determinar qual o regime de veridicção que é instaurado num
} 
O pensamento de Foucault faz-nos entender a doença como modos de uso que se convertem em estratégica política de regimes de poder que replicam culturas opressivas. Em O Nascimento da Clínica, Foucault (1977) avalia como nasceu a medicina moderna, a partir de que práticas e quais contextos históricos se configurou um novo modelo sobre esta área do conhecimento dedicada ao corpo. Vide a situação do aparelho reprodutor da mulher, que foi tido por muito tempo como passivo, enquanto que o do homem sempre foi o ativo. Adjetivos como "maltratada", "assustada", "desequilibrada" e uma série de palavras negativas foram usadas para descrever o órgão sexual feminino nas terminologias médicas (Martin, 1991; Pfeffer apud White, 2002). Já para eles, força, energia e eficiência são as características que marcam o seu sistema reprodutor e, por conseguinte, sua sexualidade. Estereótipos como esses são refletidos para o ser como um todo. Conforme surgem novos entendimentos e novas pesquisas sobre óvulos e espermatozoides, as imagens são revistas, mas as metáforas usadas como descrição são continuamente replicadas de formas diferentes (Martin, 1991). A medicalização e o discurso da ciência são fatores incontornáveis na vida da mulher e a acompanha por todos o seu percurso exercendo forte influência na sua perceção do seu próprio corpo e do que é ser mulher na nossa sociedade (White, 2002). A perspetiva de género na bioética consolidou as perceções de que o feminino e o masculino são construções sociais e não são pré-definidos pela natureza (Diniz, 2009; Diniz \& Guilhem, 2009) e, como ainda clarifica Diniz (1998, p. 136), "o problema da moralidade do aborto é histórico e contextualmente localizado e qualquer tentativa de solucioná-lo tem que levar em consideração a diversidade moral e cultural das populações atingidas".

Para Foucault, o sujeito é construído nas e pelas instituições de poder e por elas docilizados. A considerar as instituições estudadas por ele, e utilizando de forma análoga seus conceitos, como no caso as do jornalismo, o foco reside na construção e nos enquadramentos da notícia a partir de uma perspetiva crítica. Os media noticiosos são ao mesmo tempo instituições de saber e de poder porque o saber-poder atua como mecanismos de construções de verdade. A crítica à objetividade jornalística considera que o conhecimento não deve ser entendido como neutro ou inocente, mas sim como envolto em "estratégias de poder e formas relacionadas de resistência" (Andrejevic, 2008, p. 608). Apesar das críticas em torno das limitações sobre seus postulados (Vieira, 2017; Romero Pérez, 2003; Deveaux, 1994), o trabalho do filósofo é rico e potencialmente motivador para guiar os estudos jornalísticos. Estudar as notícias é estudar como as informações moldam nossas formas de pensar e de agir através da linguagem.

Um dos mecanismos de controlo é o da biopolítica, que coloca o corpo como alvo das relações de poder. É o mesmo que dizer que o sujeito está no centro de toda política e que seu corpo não é simplesmente um organismo biológico, mas sim local onde os regimes de poder atuam. Através de técnicas distintas, relacionadas à disciplina, o corpo é moldado de tal forma que as maneiras de pensar, as subjetividades, funcionam em sintonia com as maneiras de agir. O discurso constrói o corpo porque "o corpo não é apenas um texto da cultura. É também (...) um lugar prático direto de controle social” (Bordo, 1997, p. 39).

O trabalho de Foucault não sugere que tudo seja discurso. (...) Os corpos não são discursos, não são discursivos em sua materialidade. Mas os corpos não existem nem operam num vácuo não-discursivo. É claro que a palavra 'corpo' é em si uma produção discursiva, mas mais do que isso, a entidade que é o corpo está sob a soberania do discurso (Kendall \& Wickham, 1998, p. 39).

Por outras palavras, o discurso molda o conhecimento e constrói a realidade, representando-a e não a espelhando. Importa perceber que não está em causa descobrir como o presente surgiu do passado, mas sim que a História deve ser usada para diagnosticar o presente ao questionar o que é dado como certo (Kendall \& Wickham, 1998). A linguagem não classifica apenas o que é descrito, ela prescreve normas não declaradas de representações simbólicas (Foucault, 2016). O jornalismo é uma instituição que encontra no princípio da sua regularidade um regime de verdade (Foucault, 1996).

Há efeitos de verdade que uma sociedade como a sociedade ocidental, e hoje se pode dizer a sociedade mundial, produz a cada instante. Produz-se verdade. Essas produções de verdades não podem ser dissociadas do poder e dos mecanismos de poder, ao mesmo tempo porque esses mecanismos de poder tornam possíveis, induzem essas produções de verdades, e porque essas produções de verdade têm, elas próprias, efeitos de poder que nos unem, nos atam. (Foucault, 2006, p. 229)

O desafio aqui proposto é, portanto, compreender sob quais estratégias estão articulados poder e discurso mediático noticioso.

momento dado e que é precisamente aquele a partir do qual se pode agora reconhecer, por exemplo, que os médicos do século XIX disseram tantas idiotices sobre o sexo. Lembrar que os médicos do século XIX disseram muitas idiotices sobre o sexo não tem qualquer importância política. Só tem importância a determinação do regime de veridicção que lhes permitiu dizerem como verdadeiras, afirmarem como verdadeiras algumas coisas que agora sabemos serem falsas. Eis o ponto exacto em que a análise histórica pode ter alcance político. Não é a história do verdadeiro, não é a história do falso, é a história da veridcção que tem politicamente importância” (Foucault, 2010, pp. 64 e 65). 


\section{Abordagem metodológica}

Para compreender como os media brasileiros construíram as notícias sobre "Zika" e "aborto", recorremos à análise quantitativa, com vista a perceber a frequência das publicações num primeiro momento e para ancorar a segunda parte da investigação, que será desenrolada a partir da Análise Crítica do Discurso, uma análise direcionada às relações de poder na sociedade expressas através da linguagem (van Dijk, 2017; Wodak, 1999). O que se pretende neste artigo é investigar o jornalismo como regime de verdade através das suas práticas discursivas, tendo em conta os micropoderes da prática discursiva jornalística.

O corpus de análise consiste nos artigos dos jornais brasileiros da Folha de S.Paulo e $O$ Globo. A recolha de dados se deu exclusivamente nas versões online e relacionaram as palavras "Zika" e "aborto" durante o ano de 2016 e foi realizada em 2019. A pesquisa é focada no conteúdo jornalístico, tendo sido desconsiderados os artigos de opinião, as notas de colunas sociais, os blogs, os vídeos e qualquer tipo de conteúdo patrocinado. O corpus é constituído de 82 artigos, sendo 31 em $O$ Globo e 51 na Folha de S.Paulo.

Os conceitos de Foucault serão revistos durante a discussão de resultados. Para clarificar a compreensão, a organização dos dados se dá a partir da identificação de quatro âmbitos de maior frequência nos textos (religioso, médico, político e jurídico).

\section{Apresentação e discussão de resultados}

A cobertura das versões online dos dois jornais analisados (Folha de S.Paulo e O Globo) que relacionou "Zika" e aborto" concentra as publicações no primeiro semestre, anteriormente à realização dos Jogos Olímpicos no Rio de Janeiro. Fevereiro foi o mês com maior número de artigos; a Folha de S.Paulo apresentou mais peças $(N=23)$ que $O$ Globo $(N=15)$. Em janeiro, a Folha de S.Paulo apresentou 10 e $O$ Globo 4. Em março, a Folha de S.Paulo apresentou 7 e $O$ Globo 9. A partir de abril, a recorrência dos assuntos Zika e aborto caem consideravelmente, tendo $O$ Globo publicado uma peça. Em maio, é a vez da Folha de S.Paulo publicar somente uma peça enquanto $O$ Globo não referencia as palavras em conjunto. Em junho, contabilizam-se um artigo da Folha de S.Paulo e dois de $O$ Globo. Não há referências em nenhum dos dois jornais online em julho. Nos meses seguintes $O$ Globo não relaciona os dois assuntos em questão.

Em agosto, mês marcado pela realização dos Jogos Olímpicos e pela destituição do cargo de presidente de Dilma Rousseff, os assuntos relacionados foram publicados na Folha de S.Paulo uma vez. Em setembro, 3 peças; em novembro, 4 peças; e em dezembro, uma peça. No mês de outubro não houve publicação referente. Em se tratando do enfoque dado na cobertura pelo $O$ Globo, foi sobretudo aos Jogos Olímpicos dada a maior importância, enquanto que a Folha de S.Paulo abrangeu a discussão mais a nível nacional e tratou mais do assunto "aborto" relacionado à doença.

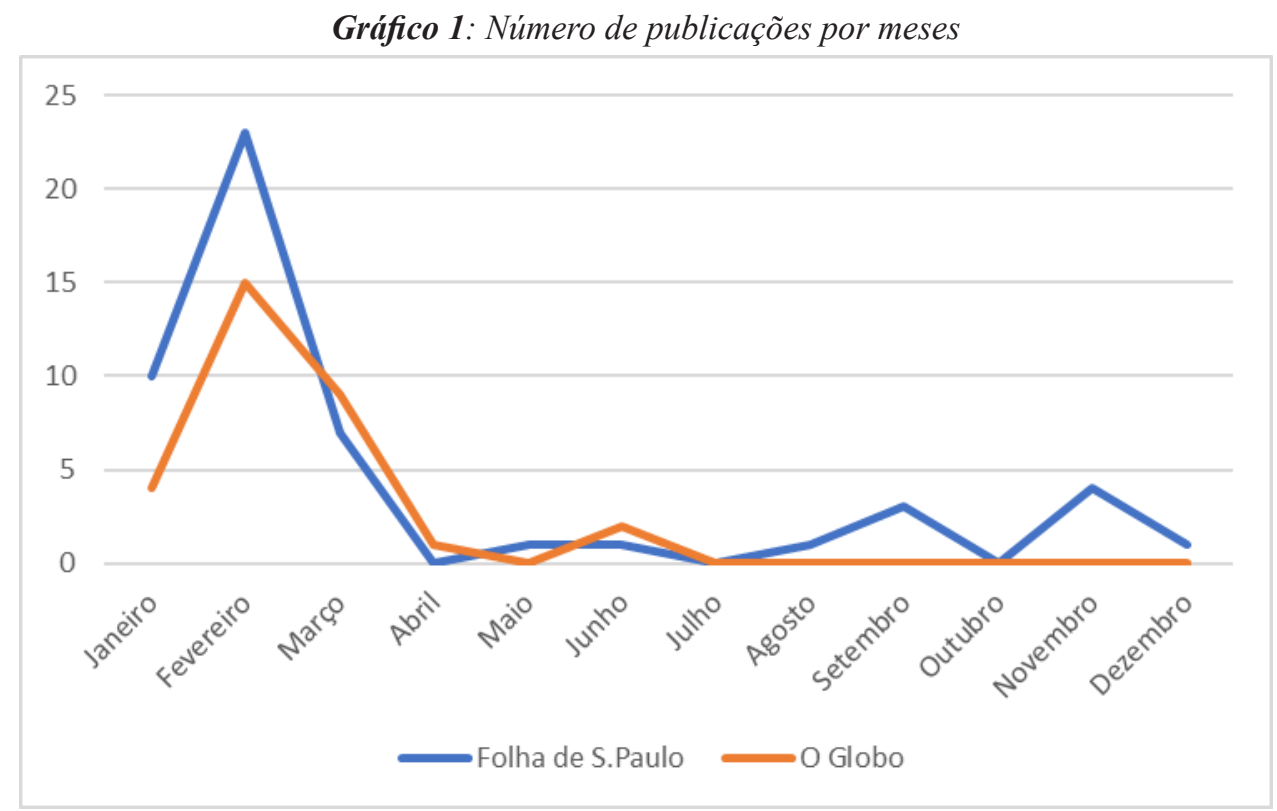

Como a seguir se indica, a problematização da Zika e da microcefalia nos media invocou discussões sobre a legalização do aborto e foi construída de forma a englobar os âmbitos médicos, jurídicos, políticos e religiosos. 


\section{1. Âmbito médico}

É comum que em casos de epidemias, desigualdades sociais sejam evidenciadas (Fabrício, 2019) e embasadas a partir da autoridade médica, que se estabelece através de estratégias de discurso que por vezes incorporam e invisibilizam outras práticas que não as científicas ou informativas. $\mathrm{O}$ discurso biomédico mediatizado se cruza, por exemplo, com processos de tomada de decisão orientados a objetivos políticos, corporativos e comerciais porque "os vírus comunicam doenças. Os signos comunicam ideologias". (Fabrício, 2019, p. 2).

O acompanhamento médico da gravidez, assim como o risco e o medo associados ao vírus Zika foram construídos a partir da relação entre a microcefalia e a Zika. A notícia da Folha de S.Paulo (26 de fevereiro de 2016) inicia com o texto: "A mãe, de 20 anos, não teve sintomas de Zika ou de qualquer outra infecção durante a gravidez. Tudo parecia bem até a $18^{\circ}$ semana de gestação, quando o feto começou a perder peso" e avança ao dizer que o bebé nasceu morto prematuramente. A morte, um valor-notícia que se sobrepõe a outros critérios de noticiabilidade (Traquina, 2001), é referida em outras peças sempre afiliada ao discurso médico. Não são encontradas alusões a casos de carência aos recursos de saúde pública nem de estrutura social e sobrevivência em meio a pobreza, como a falta de saneamento básico para contextualizar como vivem as mulheres grávidas e as famílias afetadas. Na peça da Folha de S.Paulo com o título "Placenta é alvo do zika em todas as fases da gestação" (11 de março de 2016) a presença da frase "o vírus tem preferência por infectar o cérebro dos bebês" como um resultado da análise "feita em conjunto com a patologista Lúcia de Noronha, da PUC-PR" aponta a questão como meramente biológica, um comportamento previsto do vírus Zika e que coloca as grávidas como reféns da doença.

A microcefalia é tida como consequência irreversível aos fetos. No artigo da Folha de S.Paulo (22 de novembro de 2016) com o título "Estudos mostram prejuízo causado por vírus da Zika mesmo após nascimento" são retiradas as mães do centro da questão e, já que os bebés estão vivos, realocam os pediatras e o Ministério da Saúde como fontes principais e que, por sua vez, asseguram a saúde. Fica evidente a legitimação médica no uso da voz passiva em "As crianças com mães infectadas serão acompanhadas por três anos" e em "Os pediatras precisam ficar atentos ao desenvolvimento neurológico da criança, principalmente para casos de histórico de Zika na gravidez".

No artigo da Folha de S.Paulo (11 de fevereiro de 2016) com o título "Nova pesquisa de agência americana reforça elo entre zika e microcefalia" o conselho dado para as norte-americanas foi o de ficarem atentas se seus parceiros tivessem viajado para o Brasil ou planejavam sobretudo fazê-lo durante os Jogos Olímpicos. O "alerta de risco" emitido pela CDC (Centers for Disease Control and Prevention) foi referido no artigo da Folha de S.Paulo (27 de fevereiro de 2016).

Às mulheres grávidas, a recomendação é que elas não venham ao Brasil, que se abstenham de sexo com seus parceiros durante a gestação, ou que usem preservativos, caso eles tenham vindo aos jogos.

Também há recomendação para que as mulheres que tentam engravidar falem com seus médicos antes de uma possível viagem ao Brasil ou outras áreas onde há epidemia. (EUA confirmam infecção por zika em mãe de bebê com microcefalia, Folha de S.Paulo 27 de fevereiro)

As orientações médicas para as mulheres brasileiras, tal como feito pelo governo estadunidense, também incidem na sexualidade, no corpo e nos comportamentos quotidianos. O título "Fiocruz detecta presença ativa do vírus zika em saliva e urina" em $O$ Globo (5 de fevereiro de 2016) e o trecho do texto "Principalmente no caso de gestantes, a recomendação é que evitem contato físico, como beijo na boca em pessoas com suspeita de infecção. O compartilhamento de copos e talheres deve ser evitado, assim como grandes aglomerações" evidenciam os detalhes minuciosos do controlo nas atitudes rotineiras. Percebe-se, portanto, que, nos termos de Foucault (2013), o poder é exercido em detalhes e ambiciona moldar os corpos de forma a docilizá-lo. Transformar o corpo num objeto moldável, onde cada movimento, cada gesto possa ser definido em pormenor, garantem muito mais que uma repreensão, coerção, castigo, mas sim asseguram a sujeição.

A gravidez foi patologizada uma vez que o risco da microcefalia nos bebés esteve direcionado à decisão de engravidar ou não engravidar, e, como é manifesto na peça citada acima, as mulheres deveriam tratar do assunto com os seus médicos. Delas era esperado que decidissem por não engravidar, e não por abortar. "Medo", "novo pesadelo", "risco", "problemas aos bebês" foram termos utilizadas para noticiar um possível adiamento da gravidez. Em compensação, "escolha", "família", "pai" não são palavras que estão associadas aos temas Zika e aborto.

A responsabilização está direcionada a gestante. Recordemos que, no século XIX, quando se desenvolve a ginecologia moderna, a identidade social do que é ser mulher é redefinida. A ginecologia construiu verdades que se mantiveram inquestionáveis até a década de 1960, e só com uma perspetiva feminista é que alguns métodos e preceitos médicos começaram a ser revistos (Estimado et al., 2016). O discurso da medicina, o saber especializado, foi interiorizado, ou seja, as práticas discursivas atingiram neste caso níveis silenciosos da consciência, sem que ninguém questionasse nem pensasse criticamente no que lhe era falado. Nas palavras de Foucault (1996, p. 46), "o discurso nada mais é do que a reverberação de uma verdade nascendo diante de seus 
próprios olhos; (...) tendo manifestado e intercambiado seu sentido, podem voltar à interioridade silenciosa da consciência de si". Neste sentido, o biopoder é constituído porque o poder não atua apenas na consciência, mas também e essencialmente no corpo. O corpo não é apenas objeto, ele é local de atuação, atualização e permanência do poder.

Em $O$ Globo, há a presença da voz de uma mulher infetada que teve a bebé com microcefalia. Quando a fonte fala na primeira pessoa, não é sobre a sua perceção como mãe nem sobre suas subjetividades como mulher, mas é sobre as recomendações médicas que o artigo incide.

Lara começou a fazer fisioterapia quando tinha 2 meses. A mãe se trata com psicóloga até hoje.

— Ela faz fisioterapia uma vez por semana. Mas a própria médica lá já falou que é pouco, que ela precisa fazer quase todo dia. Só que lá só atendem esses casos uma vez na semana. Fica cheio - conta Rosa Ângela, atualmente no $3^{\circ}$ ano do ensino médio; o marido de Rosa e pai de Lara, Ítalo Cassiano, tem 20 anos e faz bicos como ajudante de pedreiro. (Microcefalia: drama amplificado, $O$ Globo, 31 de janeiro de 2016)

Assim como nos trabalhos de Rozeli Porto e Patricia Moura (2017) e Fabrício (2019), foram apresentadas questões de interseccionalidade, como regionalidade, género, classe social e etnia. O relato de $O$ Globo (31 de janeiro de 2016) com o título "Microcefalia: drama amplificado" identifica uma mãe como jovem e periférica.

Aparelho nos dentes, a menina de 17 anos viu o rosto da microcefalia na sua primeira filha. Lara Safira nasceu há três meses com crânio de $28 \mathrm{~cm}$ e pegou a família de surpresa: a doença não tinha sido diagnosticada até então, apesar de a mãe ter feito pré-natal e três ultrassonografias durante a gravidez. Rosa Ângela mora com o marido e a filha do casal em Itapissuma, município da Região Metropolitana de Recife, a cerca de 45 quilômetros da capital do estado que mais tem registrado casos de microcefalia no Brasil. (Microcefalia: drama amplificado, $O$ Globo, 31 de janeiro de 2016)

O estigma da mulher pobre acompanha as narrativas dos dois veículos, deixando claras as dificuldades de acesso a estruturas básicas que garantam uma qualidade de vida e de escolha em relação ao procedimento (ou não) do aborto. Na Folha de S.Paulo (23 de dezembro de 2016), o artigo leva a crer numa divisão socioeconómica baseada em etnia e região ao vincular o nordeste brasileiro a mulheres negras e pardas e o sudeste a mulheres brancas.

O estigma da pobreza se repete na peça intitulada "Grávidas com zika fazem aborto sem confirmação de microcefalia", também da Folha de S.Paulo (31 de janeiro de 2016). Enquanto as mulheres que são casadas, possuem educação de nível superior "se desesperam" e optam por interromper a gravidez, outras se sujeitam a condições precárias e não lhes é permitido escolha, nem a nível jurídico nem a nível económico, para realizar o aborto. A sujeição é, como nos fala Foucault (2014, p. 29), "calculada, organizada, tecnicamente pensada, pode ser sutil, não fazer uso de armas nem do terror, e, no entanto, continuar a ser de ordem física".

\section{2 Âmbito jurídico}

No âmbito jurídico, a decisão da mulher não é problematizada. As mulheres grávidas e infetadas não falam por si mesmas nestas instâncias. Em linha com a pesquisa de Castilhos \& Almeida (2020), em que as fontes médicas e jurídicas são vistas como privilegiadas na cobertura mediática, no corpus estudado estão expressas apenas declarações de porta-vozes. Na Folha de S.Paulo, nenhuma mulher que falasse sobre sua experiência pessoal foi ouvida, e a visão masculina do papel do pai não foi considerada. Os títulos e os artigos apresentam autoridades jurídicas e políticas a tratar de legislação referente ao corpo da mulher sem ao menos colocá-las no centro do debate, seus corpos são regulados por instâncias que baseiam suas decisões em entendimentos políticos. Acontecimentos excecionais, como altos índices de não-desenvolvimento do feto em caso de agravamento da contaminação pelo vírus Zika, não surtiram efeito nas argumentações a favor de um debate democrático e igualitário sobre o aborto legal nos media mainstream analisados.

As mulheres são apresentadas por números, por percentagens, por estatísticas. Esta prática é vista em $O$ Globo (3 de fevereiro de 2016, excerto abaixo) quando notificam relatórios e boletins médicos. As fontes oficiais no relato noticioso, nomeadamente a Organização Mundial da Saúde e o Ministério da Saúde, possuem espaço privilegiado nas peças. Em artigo de $O$ Globo (11 de fevereiro de 2016) intitulado "OMS: Maioria das grávidas de países com Zika dará à luz crianças normais", lê-se: "a OMS voltou a pedir às grávidas que se protejam durante o período de gestação, cobrindo o corpo, usando repelentes e camisinha". Os números e percentagens aparecem no título e subtítulo de matéria de $O$ Globo (27 de janeiro de 2016): "Brasil tem 270 casos confirmados de microcefalia; 6 têm relação com a Zika" seguido de "Outras 462 notificações já foram descartadas pelo Ministério da Saúde". O mesmo é expresso nos excertos abaixo.

O Ministério da Saúde informou também que em 17 casos de microcefalia ficou comprovada a relação com o vírus zika, embora a Organização Mundial da Saúde (OMS) ainda não reconheça esta relação oficialmente. Os 
dados do boletim vão até 30 de janeiro. No Estado do Rio, os registros de casos suspeitos passaram de 122 para 208, um aumento de 70\%. Mas, desse total, 10 já foram descartados, e dois, confirmados. (Ministros da Saúde vão discutir combate ao Aedes em Montevidéu, $O$ Globo, 3 de fevereiro de 2016)

Com o censo populacional, o Estado começa a contabilizar o número de mortalidade, nascimentos, saúde, higiene, e a encontrar novas formas de organizar, categorizar, hierarquizar e controlar a população. A esse mecanismo Foucault (2010) dá o nome de biopolítica e o separa do modo absolutista de reinar, quando o soberano decidia quem ia morrer e quem ia deixar viver. Esta tecnologia da vida atua através de práticas disciplinares e a somar com a anatomo-política, que atua no indivíduo, no pessoal, no íntimo, na minucia, faz emergir o biopoder. E com ele, entra em cena o saber-poder, um regime de verdade que articulado pelas práticas jurídicas (assim como as práticas do discurso jornalístico) constroem regras, disciplinas e punições, porque "poder e saber estão diretamente implicados; que não há relação de poder sem constituição correlata de um campo de saber" (Foucault, 2014, p. 31). O funcionamento jurídico-antropológico que Foucault (2014, p. 180) se encarrega de esmiuçar em Vigiar e Punir "não se origina na superposição à justiça criminal das ciências humanas, (...) tem seu ponto de formação nessa técnica disciplinar que fez funcionar esses novos mecanismos de sanção normalizadora" que, no caso em análise, está também vinculado aos âmbitos políticos e morais religiosos.

\section{3. Âmbito político}

Os discursos políticos foram mobilizados no contexto do ano de 2016, que envolveram os Jogos Olímpicos no Rio de Janeiro e o impeachment da então presidente Dilma Rousseff. Dois argumentos foram utilizados na cobertura: um que defendia a legalização do aborto, enquanto o outro que defendia a vida. A discussão sobre a interrupção da gravidez aparece apenas em situações que envolvem o vírus Zika, não sendo englobados atos abortivos para outros casos. A aceção da biopolítica de Foucault é mais uma vez vista neste caso, que tem seu início com a discussão no âmbito jurídico. Ou seja, emergem as ideias de que o Estado deve tomar conta da população, de que é o Estado o responsável por definir e gerir a vida de cada cidadã e cidadão (Foucault, 2010). Aqui se desdobra outro conceito, o de governamentalidade - um neologismo que explica a maneira de guiar a conduta do sujeito. A governamentalidade é um mecanismo de "governo dos outros (governo político, doméstico, religioso, educacional) e o governo de si mesmo (autodomínio, autocontrole)" (Candiotto, 2012, p. 105).

— Temos que provar que esse país com mais de 200 milhões é mais forte do que esse mosquito. Vocês, que estão recebendo as chaves, olhem para dentro de suas residências e não deixem acumular água limpa ou suja. É dentro de nossas casas que estão $2 / 3$ dos focos. Temos capacidade de acabar com esses mosquitos antes que ele comprometa nossas crianças e nossas mães grávidas. (Dilma pede que Brasil seja 'mais forte do que esse mosquito', $O$ Globo, 3 de fevereiro de 2016)

Em artigo da Folha de S.Paulo (1 de março de 2106) intitulado "Brasil pode protagonizar 'escândalo global', diz professor da USP sobre Zika" o âmbito político representado pela figura do ministro da Saúde, Marcelo Castro, é legitimado pelo discurso médico. O porta-voz do governo é visto pelo meio de comunicação com desconfiança ao tratar da relação Zika-microcefalia, exposto pelo uso dos verbos "costuma apontar" e pela escolha de sua fala citada diretamente com sinais de pontuação (interrogação e exclamação) que não transparece objetividade científica.

"No início de 2015, tivemos epidemia de zika no Nordeste. Nove meses depois, uma epidemia de microcefalia. Onde? Exatamente no Nordeste. Epidemiologicamente está estabelecida a relação", disse o ministro à imprensa (Brasil pode protagonizar 'escândalo global', diz professor da USP sobre Zika, Folha de S.Paulo, 1 de março de 2016).

\section{4. Âmbito religioso}

A religiosidade é resumida a apenas duas práticas religiosas nos dois jornais analisados. A religião católica possui espaço nos media através da voz que recebe pela Conferência Nacional dos Bispos do Brasil (CNBB) e a evangélica é associada à política. Em 'A Vontade de Saber', primeiro volume de 'História da Sexualidade', Foucault (2001) posiciona a sexualidade como “um 'dispositivo histórico' e não um 'referente biológico'. Na verdade, a sexualidade é um dos dispositivos que visam dominar o corpo e o desejo, um dispositivo datado do séc. XIX" (Cardoso Jr, 2010, p. 171). Portanto, os assuntos aborto e epidemia da Zika regulam inclusive as relações sexuais, indo além das questões que envolvem contraceção e da decisão de se e quando engravidar.

Na peça "Renan defende decisão do STF sobre nova interpretação do aborto" da Folha de S.Paulo (30 de novembro), é referenciada a "bancada evangélica" não como crença religiosa, mas sim como a frente 
parlamentar do Congresso Nacional brasileiro. No trecho há a presença de vocábulos de ordem políticalegislativa: "Para se contrapor aos ministros, Maia atendeu a pedidos vindos especialmente da bancada evangélica e disse que vai instalar uma comissão especial para rever a deliberação do Supremo". O assunto de cunho político do direito reprodutivo também envolve o religioso no que se refere à doutrina católica, como mostrado no excerto abaixo.

Há também grupos religiosos favoráveis ao direito ao aborto, como a Católicas pelo Direito de Decidir. "A criminalização tem sido inócua, não impede que mulheres continuem abortando, só coloca em risco mulheres que recorrem a clínicas clandestinas de péssimas condições", diz Rosângela Talib, coordenadora da ONG. "A interdição religiosa, que considera pecado mortal, também não tem impactado, a não ser negativamente na vida e na saúde das mulheres", continua.

Para o Dom Frei João Bosco Barbosa de Sousa, da CNBB (Confederação Nacional dos Bispos do Brasil), a questão vai além da religião. "Trata-se de um direito de um indefeso. A vida é o dom mais precioso que a gente tem. É uma agressão a um indefeso, e não a defesa do direito reprodutivo ou qualquer coisa assim. Trata-se de um direito à vida", diz. (Decisão de ministros do STF de que aborto não é crime divide entidades, Folha de S.Paulo, 30 de novembro de 2016)

No corpus analisado, a religião católica é a única a ser conjugada com a moral cristã. Na fala do representante católico, o bispo dom Leonardo Steiner, é expressa a ideia de que todas as mulheres possuem o dom natural da maternidade: "os números mostram que a mulher tem uma sensibilidade maior que os homens nesse quesito porque é a mulher 'que tem a grandeza da maternidade' (Há maior senso de humanidade entre pobres, diz CNBB sobre microcefalia, Folha de S.Paulo, 29 de fevereiro de 2016).

É, portanto, crucial de se pontuar que os media projetam para o "espaço público as exigências culturais e normativas que lhes estão associadas" e dão, assim, visibilidade e invisibilidade a temas que são enquadrados conforme entendimentos e informações de parte da sociedade (Silveirinha, 2008, p. 465). Faz-se importante ressaltar ainda que o poder, para Foucault (2006), é exercido e garantido através de relações de poder. Não seria de outro modo possível manter certas práticas e certos mecanismos de controlo em torno dos indivíduos se não houvesse microlutas e enfrentamentos. Foucault não traz soluções para a sociedade - seu objetivo era questionar e não responder. Mas, em seus trabalhos tardios, o autor apresenta a noção de resistência que pode, tanto através de micropoderes quanto de macropoderes, operar mudanças nas relações de poder encontradas na sociedade.

\section{Conclusão}

O que se pretendeu neste trabalho foi dar atenção em como as práticas sociais, em especial as discursivas jornalísticas, influenciam o modo de pensar e de agir, tanto no que diz respeito a própria mulher quanto à relação com as outras pessoas. Quando pensamos em poder, pensamos em relações de poder; quando pensamos em discurso, pensamos em práticas discursivas.

A partir dos conceitos foucauldianos e da Análise Crítica do Discurso, pôde-se observar com maior atenção o que foi dito e normalizado e o que não foi dito e, por sua vez, negligenciado. Embora a Organização Mundial da Saúde não tenha afirmado inicialmente que a microcefalia estava relacionada ao vírus Zika, este vínculo começou a ser expresso nas notícias como norma por porta-vozes médicos e políticos depois que a ligação causal foi referendada em pesquisas científicas. Com esta verdade estabelecida, a legalização do aborto começou a ser problematizada, e foi feita com mais ênfase pela Folha de S.Paulo.

Nenhuma mulher teve sua experiência pessoal contada durante a cobertura da Folha de S.Paulo. O tema aborto não foi abordado na esfera privada e a cobertura foi exclusivamente focada nos âmbitos jurídicos, políticos e religiosos, deixando questões médicas fora da problemática, embora as vozes médicas tenham sido consultadas como fontes mediáticas no Brasil. A moral religiosa foi restrita à religião católica. Embora a evangélica também tenha sido citada, foi sempre associada à política. $\mathrm{O}$ aborto foi assunto inadmissível na esfera religiosa. A gravidez foi patologizada, tendo sido associados o medo e o risco de malformação dos fetos como uma influência na decisão das mulheres em engravidar ou não. Apesar de poucas, foram apresentadas questões de interseccionalidade, que consideraram a doença um problema do Nordeste brasileiro e de mulheres negras e pobres.

O discurso jurídico acompanhou a cobertura da Folha de S.Paulo e o discurso político acompanhou a de $O$ Globo. Os contextos político-económicos do ano de 2016 mobilizaram interesses e envolveram o impeachment da então presidente Dilma Rousseff e a realização dos Jogos Olímpicos no Rio de Janeiro.

Resumindo e concluindo, a análise mostrou que em relação ao discurso jornalístico, houve reprodução de discursos das esferas médica, religiosa, legislativa e política. E foi ainda possível perceber como as questões de saúde pública governaram o corpo e as decisões das mulheres, servindo como plataforma política e limitando as possibilidades delas em deliberarem sobre seus corpos. Nos termos de Foucault, as práticas discursivas 
jornalísticas ajudaram a reforçar a sujeição do corpo e da mente das mulheres num processo de sustentação, reforço e multiplicação das relações de poder.

\section{Referências bibliográficas}

Aguiar, R., \& Araujo, I. S. (2016). A mídia em meio às 'emergências' do vírus Zika: questões para o campo da comunicação e saúde. RECIIS - Rev Eletron Comun Inf Inov Saúde. 10(1), 1-15.

Bordo, S. (1997). O corpo e a reprodução da feminidade: Uma apropriação feminista de Foucault. In Jaggar, A. M. \& Bordo, S. Gênero, corpo, conhecimento. Rio de Janeiro: Rosa dos Tempos.

Candiotto, C. (2012). A governamentalidade em Foucault: da analítica do poder à ética da subjetivação. O que nos faz pensar, 21(31), 91-108.

Cardoso Jr, H. R. (2010). Corpo e sexualidade entre disciplina e biopolítica. In L. A. F. Souza; T. T. Sabatine; B. R. Magalhães (org.), Sexualidade, Corpo e Direito, pp. 155-175.

Castilhos, W. (2018) Título: Qual a palavra que nunca foi dita? Vozes e discursos nas notícias sobre zika-microcefaliaaborto. (Dissertação de mestrado, Casa de Oswaldo Cruz, Fundação Oswaldo Cruz, Rio de Janeiro, Brasil). Disponível a partir de https://www.arca.fiocruz.br/bitstream/icict/31100/2/dissertacao_washington_castilhos.pdf

Castilhos, W., \& Almeida, C. (2020). Discursos sobre o aborto na epidemia de Zika: análise da cobertura dos jornais O Globo e Folha de S. Paulo. Cadernos de Saúde Pública, 36, 1-14.

Chamberlian, K., Stephens, C., \& Lyons, A. C. (1997). Encompassing experience: meanings and methods in health psychology. Psychology and Health, 12(5), 691-709.

Danfá, L., \& de Morais, E. R. C. (2017) Bioética e zika vírus na imprensa brasileira: reflexões psicossociais. Psicologia e Saber Social, 6(2), 274-287.

Deveaux, M. (1994). Feminism and empowerment: A critical reading of Foucault. Feminist studies, 20(2), 223-247.

Diniz, D. (2009). Bioética e gênero. Revista Bioética, 16(2), 207-216.

Diniz, D., \& Almeida, M. D. (1998). Bioética e aborto. Iniciação à bioética. Brasília: Conselho Federal de Medicina, 125-137.

Diniz, D., \& Guilhem, D. (2009). Bioética feminista: o resgate político do conceito de vulnerabilidade. Revista Bioética, 7(2).

Diniz, D., Medeiros, M., \& Madeiro, A. (2017). Pesquisa nacional de aborto 2016. Ciência \& Saúde Coletiva, 22, 653660.

Estimado, R. B., Fortunato, T., Cruz, J. F. A., Hotimsky, M. C. N., \& Bassani, A. D. (2016). Entrevista: Margareth Rago. Humanidades em diálogo, 7, 15-43.

Fabrício, B. F. (2019). Discourse circulation in news coverage of the Zika virus outbreak: Colonial geopolitics, biomediatization and affect. Discourse, Context \& Media, 30, 1-10.

Foucault, M. (1977). O Nascimento da Clínica. Rio de Janeiro: Forense-Universitária.

Foucault, M. (1996). A Ordem do Discurso. São Paulo: Edições Loyola.

Foucault, M. (2001). História da sexualidade I: a vontade de saber. (14. ed.) Rio de Janeiro: Graal.

Foucault, M. (2006). Estratégia, Poder-Saber. (2 ed) Rio de Janeiro: Editora Forense Universitária.

Foucault, M. (2010). Nascimento da Biopolítica. Lisboa: Edições 70.

Foucault, M. (2010). O Nascimento da Biopolítica. Lisboa: Edições 70.

Foucault, M. (2013). É Preciso Defender a Sociedade. Rio de Janeiro: Forense Universitária.

Foucault, M. (2014). Vigiar e Punir. Petrópolis, RJ: Editora Vozes.

Foucault, M. (2016). Arqueologia do Saber. Lisboa: Edições 70.

Frewer, L. (2001). Public risk perceptions and risk communication. In Risk Communication and Public Health. Bennett, P.; Calman, KC. (ed). Oxford: Oxford University Press.

Haglin, K., Chapman, D., Motta, M., \& Kahan, D. (2019). How Localized Outbreaks and Changes in Media Coverage Affect Zika Attitudes in National and Local Contexts. Health communication, 1-12.

Hamberg, K. (2008). Gender bias in medicine. Women's health, 4(3), 237-243.

Jerit, J., Zhao, Y., Tan, M., \& Wheeler, M. (2018). Differences between national and local media in news coverage of the Zika virus. Health communication, 34(14), 1816-1823,

Kendall, G., \& Wickham, G. (1998). Using Foucault's methods. London: Sage.

Lupton, D. (1992). Discourse analysis: Anew methodology for understanding the ideologies of health and illness. Australian journal of public health, 16(2), 145-150.

Lyons, A. C. (2000). Examining media representations: Benefits for health psychology. Journal of health psychology, 5(3), 349-358.

Maia, L. F. M. P., \& Yagui, M. M. M. (2017). Triplificação de dados de notícias sobre a Zika. Anais do XIII Simpósio Brasileiro de Sistemas de Informação (Lavras, 2017), 40-47.

Martin, E. (1991). The egg and the sperm: How science has constructed a romance based on stereotypical male-female roles. Signs: Journal of Women in Culture and Society, 16(3), 485-501. 
Martins, M. N. (2016) Rio 2016: Zika Vírus e a Defasagem Noticiosa entre o On-line e o Impresso no Agendamento das Olimpíadas do Brasil. Intercom - Sociedade Brasileira de Estudos Interdisciplinares da Comunicação $39^{\circ}$ Congresso Brasileiro de Ciências da Comunicação. São Paulo, SP, 1-15.

Porto, R. M., \& Moura, P. R. S. (2017). O Corpo Marcado: a construção do discurso midiático sobre Zika Vírus e Microcefalia. Cadernos de Gênero e Diversidade, 3(2), 158-191.

Regitz-Zagrosek, V., \& Seeland, U. (2013). Sex and gender differences in clinical medicine. Sex and Gender Differences in Pharmacology, 3-22. Munich: Springer

Romero Pérez, R. (2003). En torno al pensamiento crítico: Michel Foucault y la teoría feminista. Madrid: Universidad Complutense de Madrid, Servicio de Publicaciones.

Sell, T. K., Watson, C., Meyer, D., Kronk, M., Ravi, S., Pechta, L. E., ... \& Rose, D. A. (2018). Frequency of risk-related news media messages in 2016 coverage of Zika virus. Risk Analysis, 38(12), 2514-2524.

Silveirinha, M. J. (2008). Licença para (não) reproduzir: os direitos sexuais e reprodutivos no espaço mediático, Revista Filosófica de Coimbra, 34, pp. 461-494.

Tinga, T., Pruchniewska, U., Buozis, M., \& Kute, L. (2018). Gendered discourses of control in global journalism: women's bodies in CNN's Zika reporting. Feminist Media Studies, 1-16.

Traquina, N. (2001). O estudo do jornalismo no século XX. São Leopoldo: Unisinos.

van Dijk, T. A. (2017). Discurso, notícia e ideologia: estudos na análise crítica do discurso. Famalicão: Edições Húmus.

Vieira, P. P. (2017). Michel Foucault e Jacques Léonard sobre Vigiar e Punir: os embates entre a história e a loso a. DoisPontos, 14(1), 37-49.

White, K. (2002). An introduction to the sociology of health \& illness. London: Sage Publications.

Wodak, R. (1999). Critical discourse analysis at the end of the 20th century. Research on Language \& Social Interaction, 32(1-2), 185-193.

Rubin, E. J., Greene, M. F., \& Baden, L. R. (2016). Zika virus and microcephaly, 374, 984-985. 
